\title{
ВПЛИВ ХОЛЕКАЛЬЦИФЕРОЛУ \\ НА ІМУНОГЕННІСТЬ ВАКЦИНИ ПРОТИ ГРИПУ ТА ЦИТОКІНОВИЙ СТАТУС В ОСІБ ПОХИЛОГО ВІКУ
}

\author{
Грішина О. І., Менкус О. В.
}

\section{ВСТУП}

Профілактика респіраторних інфекцій у осіб похилого віку на цей час обмежується рекомендаціями вакцинації проти грипу і пневмонії. Однак пандемія COVID-19 показала, що ми не завжди можемо сподіватися на досягнення медицини у вигляді вже створених вакцин, нам також необхідна власна адекватна відповідь імунної системи на збудник хвороби. Тим більше, що австралійськими вченими було показано, що імунна система людей реагує на коронавірус так само, як вона зазвичай бореться 3 грипом: «Збільшення клітин, що секретують антитіла, фолікулярних хелперних Т-клітин, активованих CD4+ (від англ. claster of differentiation) T-клітин і CD8+ T-клітин, антитіл Ig (імуноглобулін) M i IgG до коронавірусу SARS-CoV-2, який викликає COVID-19, виявлялися в крові до симптоматичного одужання. Ці імунологічні зміни зберігалися протягом не менше як 7 днів після повного усунення симптомів» ${ }^{1}$. $Є$ цілий ряд досліджень, присвячених ефективності вітаміну D3 для профілактики гострих респіраторних вірусних інфекцій (ГРВI). Деякі 3 них вельми однозначно показують його користь. Так, наприклад, А. Adit та співавтори ${ }^{2}$ однозначно показують, що щомісячні високі дози вітаміну D3 знижують частоту виникнення ГРВІ у літніх людей. Учасники (55 осіб, які отримували високі дози і 52 - на стандартних дозах) були рандомізовані і включені в остаточний аналіз. У групі з високими дозами було 0,67 ГРВІ на людину в рік, а в групі зі стандартними дозами - 1,11 (коефіцієнт захворюваності $($ IRR $)=0,60$, CI 95\% $=0,38-0,94, p=0,02)$. Падіння були частішими в групі високих доз (1,47 на людину в рік проти 0,63 в групі стандартних доз; IRR = 2,33, 95\%, CI = 1,49-3,63, p <0,001). Переломи були рідкісними і однаковими в обох групах (висока доза 0,10 проти стандартної дози 0,19 на людину в рік; $\mathrm{p}=0,31)$. Середні рівні вітаміну D3 в процесі

\footnotetext{
${ }^{1}$ Thevarajan I. Breadth of concomitant immune responses prior to patient recovery: a case report of non-severe COVID-19. Nat Med, 2020. DOI: https://www.nature.com/ articles/s41591-020-0819-2.

2 Adit A., Blatchford P., Breese K. et al. High-Dose Monthly Vitamin D for Prevention of Acute Respiratory Infection in Older Long-Term Care Residents: A Randomized Clinical Trial. Epub., 2016. DOI: 10.1111/jgs.14679.
} 
дослідження склали 32 нг/мл в групі з високою дозою і 25,1 нг/мл в групі зі стандартною дозою. В обох групах не було гіперкальціємії або каменів в нирках. Проте один із масштабних метааналізів ${ }^{3}$ закликає 3 обережністю ставитись до інтерпретації даних через неоднорідність досліджень i можливих зміщень, хоча загалом після аналізу 11 плацебо-контрольованих досліджень (відібраних 31 137), у яких налічувалося 5660 пацієнтів загалом, вітамін D3 показав захисну дію проти респіраторних вірусних інфекцій $(\mathrm{OR}=64 ; 95 \%$ СI від 0,49 до 0,84). У дослідженнях спостерігалася значна гетерогенність (Cochran's $\mathrm{Q}<0,0001, \mathrm{I} 2=72 \%$ ). Захисний ефект був вищим у дослідженнях з використанням дозування - один раз на день в порівнянні з болюсними дозами $(\mathrm{OR}=0,51$ проти $\mathrm{OR}=0,86, \mathrm{p}=0,01)$. Ali Daneshkhah та співавтори ${ }^{4}$, вивчаючи можливу роль вітаміну D3 у придушенні цитокінового шторму та пов'язаної з ним смертності у пацієнтів з COVID-19, дійшли висновку, що є зв'язок між високим СРБ (C-реактивний білок) та дефіцитом вітаміну $\mathrm{D} 3$ ( $\mathrm{OR}=1,8,95 \%$ CI от 1,2 до 2,6 ) серед літніх людей (вік більше або рівний 60 років). 3 огляду на те, що СРБ $є$ сурогатним маркером шторму цитокінів і пов'язаний з дефіцитом вітаміну D3, на підставі ретроспективних даних і непрямих даних автори бачать можливу роль вітаміну D3 в зниженні ускладнень, пов'язаних 3 нерегульованим запаленням і штормом цитокінів.

Метою цього етапу була оцінка імуногенності вакцини проти грипу та цитокінового статусу в осіб похилого віку на фоні прийому холекальциферолу, вакцини проти грипу та їх комбінації.

\section{1. Матеріали та методи}

Об'єктом дослідження було 200 осіб, серед яких було 102 (51\%) жінки і 98 (49\%) чоловіків віком від 65 до 79 років, середній вік яких склав $(\mathrm{M} \pm \mathrm{SD})(72,4 \pm 7,1)$ років.

Критеріями невключення в дослідження були: наявність в анамнезі алергічних реакцій на курячий білок або на будь-яку попередню вакцинацію грипозною вакциною; лейкоз i iнші онкологічні захворювання; гепатити В і С, сифіліс, інфікування вірусом імунодефіциту людини, синдром Гійєна-Баре; дані про отримання препаратів імуноглобуліну або крові протягом останніх трьох місяців до початку дослідження; тривале використання імуносупресантів або імунодефіцитний стан; дані про те, що доброволець перебуває на обліку в

${ }^{3}$ Bergman P., Lindh U., Björkhem-Bergman L.et al. Vitamin D and Respiratory Tract Infections: A Systematic Review and Meta- Analysis of Randomized Controlled Trials. 2013. DOI: 10.1371/journal.pone.0065835.

${ }^{4}$ Daneshkhah A., Agrawal V., Eshein A. et al .The Possible Role of Vitamin D in Suppressing Cytokine Storm and Associated Mortality in COVID-19 Patients. 2020. DOI: https://doi.org/10.1101/2020.04.08.20058578. 
туберкульозному, наркологічному або психоневрологічному диспансері; наявність гострих або загострених на момент дослідження хронічних захворювань інфекційної та неінфекційної природи; зловживання алкоголем; вживання наркотиків; участь у будь-якому іншому клінічному дослідженні протягом останніх трьох місяців; наявність аутоімунних захворювань; особи, що отримують імуносупресивну терапію.

Контрольну групу для лабораторних показників склали 50 відносно здорових осіб віком до 65 років, яких було вакциновано проти грипу.

Усі учасники дослідження підписали інформовану згоду, складену відповідно до Інструкції щодо заповнення форми первинної облікової документації № 003-6/о «Інформована добровільна згода пацієнта на проведення діагностики, лікування та на проведення операції та знеболення», Наказу МО3 України № 110 від 14.02.2012 «Про затвердження форм первинної облікової документації та інструкцій щодо їх заповнення, що використовуються у закладах охорони здоров'я незалежно від форми власності та підпорядкування» ${ }^{5}$.

Для щеплення в 2018 році використовували вакцину «Ваксігрип» (SANOFI PASTEUR, S.A., Франція). Холекальциферол призначали по 2000 МО на день.

Визначення кількості лімфоцитів у периферийній крові з антигенними детермінантами CD проводили з використанням набору MultiTEST IMK kit (CD3 / CD4 / CD8 / CD19 / CD56), виробництво BD Multitest, CША. Рівні інтерлейкіна (ІЛ) 4, ІЛ-19, ІЛ-23 і ІФН- $\gamma$ в периферійній крові визначали методом імуноферментного аналізу з використанням наборів "DRG Interleukin 4”, "DRG Interleukin 19”, "DRG Interleukin 23”, "DRG Interferon gamma" виробництво DRG International, Inc., США, відповідно. Рівень холекальциферолу в периферійній крові визначали шляхом імуноферментного аналізу з використанням наборів "DRG 25-OH Vitamin D”, виробництво DRG International, Inc., США. Вміст антитіл до вірусу грипу типу A (H1N1, H3N2) і типу В у сироватці крові за допомогою реакції гальмування гемаглютинації (РГГФ) 3 використанням наборів готових реактивів «Діагностикум грипозний для РГГА, тип А (H1N1)», «Діагностикум грипозний для РГГА, тип А (H3N2)», «Діагностикум грипозний для РГГА, тип В» (ВАТ «Укрмедиаснаб», Україна).

Статистичний аналіз проводився 3 використанням пакету статистичних програм SPSS версії 15.0. Поріг статистичної похибки різних тестів був встановлений на рівні 5\%. Характер даних описової статистики залежав від типу змінних. Розраховували середнє значення,

\footnotetext{
${ }^{5}$ Наказ МО3 України №110 від 14.02.2012 «Про затвердження форм первинної облікової документації та інструкцій щодо їх заповнення, що використовуються у закладах охорони здоров'я незалежно від форми власності та підпорядкування». URL: https://www.moz.gov.ua/ua/portal/dn_20120214_110.html.
} 
суму, стандартне відхилення, мінімум і максимум для безперервних змінних і частоту і процентні частини для порядкових або номінальних змінних. Для порівняння даних використовували t-тест (Ст’юдента), Вілкоксона і критерій хі квадрат.

\section{2. Отримані результати}

Після рандомізації пацієнтів було розподілено по 4 групах. Пацієнти в групі 1 почали прийом холекальциферолу і отримали вакцину проти грипу. Пацієнти в групі 2 отримали тільки вакцину проти грипу. Пацієнти в групі 3 - тільки холекальциферол. Пацієнти групи 4 обмежилися виконанням загально-гігієнічних заходів.

Групу 1 склало 50 осіб, серед яких було 26 (52\%) жінок і 24 (48\%) чоловіки віком від 65 до 79 років, середній вік яких склав $(\mathrm{M} \pm \mathrm{SD})$ $(72,4 \pm 7,5)$ років. У групу 2 увійшло 49 осіб, з них було 24 (49\%) жінки і 25 (51\%) чоловіків віком від 65 до 77 років, середній вік яких склав $(\mathrm{M} \pm \mathrm{SD})(71,9 \pm 7,2)$ років. Групу 3 склало 52 особи, серед яких було $26(50 \%)$ жінок і $26(50 \%)$ чоловіків віком від 65 до 78 років, середній вік яких склав $(\mathrm{M} \pm \mathrm{SD})(72,1 \pm 6,1)$ років. У групу 4 увійшло 49 осіб, 3 них було 26 (53\%) жінок і 23 (47\%) чоловіки віком від 65 до 77 років, середній вік яких склав $(\mathrm{M} \pm \mathrm{SD})(70,5 \pm 6,4)$ років. Всі групи були співставні за віком і статтю, $\mathrm{p}>0,05$.

У всіх пацієнтів була діагностована поліморбідна патологія, що розподілилася за частотою таким чином (наведено перші 10 нозологій): 1) артеріальна гіпертензія (АГ); 2) ішемічна хвороба серця (IXC); 3) остеоартроз (ОА), в тому числі остеохондроз; 4) хронічний панкреатит; 5) хронічний холецистит, в тому числі жовчно-кам'яна хвороба; 6) хронічне обструктивне захворювання легень (ХОЗЛ); 7) сечо-кам'яна хвороба; 8) хронічний пієлонефрит; 9) ожиріння, 10) остеопенія / остеопороз. Основний діагноз - АГ був у 116 (58\%) паціснтів, IXC - у 68 (34\%), ОА - у 16 (8\%).

Загалом АГ спостерігали у пацієнтів всіх чотирьох груп 3 наступною частотою (табл. 1).

Таблиця 1

Розподіл паціснтів за стадісю АГ, n (\%)

\begin{tabular}{|c|c|c|c|c|}
\hline Стадія & $\begin{array}{c}\text { Група 1, } \\
\mathbf{n = ~ 7 0}\end{array}$ & $\begin{array}{c}\text { Група 2, } \\
\mathbf{n = 6 9}\end{array}$ & $\begin{array}{c}\text { Група 3, } \\
\mathbf{n = ~ 7 2}\end{array}$ & $\begin{array}{c}\text { Група 4, } \\
\mathbf{n = 6 9}\end{array}$ \\
\hline I & $8(11,43 \%)$ & $7(10,14 \%)$ & $11(15,26 \%)$ & $9(13,04 \%)$ \\
\hline II & $21(30 \%)^{1)}$ & $26(37,68 \%)^{1)}$ & $22(30,55 \%)^{1)}$ & $22(31,88 \%)^{1)}$ \\
\hline III & $10(14,28 \%)$ & $10(14,49 \%)$ & $10(13,89 \%)$ & $9(13,04 \%)$ \\
\hline
\end{tabular}

Примітка: $\mathrm{n}$ - кількість пацієнтів, ${ }^{1)}$ - достовірність різниці показників в середині груп 
Згідно з табл. 1 достовірно частіше серед пацієнтів всіх чотирьох груп спостерігали другу стадію АГ, ніж першу і третю, $\mathrm{p}>0,05$.

Таблиця 2

Розподіл паціснтів за ступенем АГ, $\mathbf{n}(\%)$

\begin{tabular}{|c|c|c|c|c|}
\hline Ступінь & $\begin{array}{c}\text { Група 1, } \\
\mathbf{n = ~ 7 0}\end{array}$ & $\begin{array}{c}\text { Група 2, } \\
\mathbf{n = 6 9}\end{array}$ & $\begin{array}{c}\text { Група 3, } \\
\mathbf{n = ~ 7 2}\end{array}$ & $\begin{array}{c}\text { Група 4, } \\
\mathbf{n = 6 9}\end{array}$ \\
\hline 1 & $9(12,86 \%)$ & $10(14,49 \%)$ & $11(15,28 \%)$ & $10(14,49 \%)$ \\
\hline 2 & $24(34,28 \%)^{1)}$ & $26(37,68 \%)^{1)}$ & $24(33,33 \%)^{1)}$ & $23(33,33 \%)^{1)}$ \\
\hline 3 & $7(10 \%)$ & $7(10,14 \%)$ & $8(11,11 \%)$ & $6(8,69 \%)$ \\
\hline
\end{tabular}

Примітка: $\mathrm{n}$ - кількість пацієнтів, ${ }^{1)}$ - достовірність різниці показників у середині груп

Обстежені пацієнти всіх груп достовірно частіше мали АГ другого ступеню, $\mathrm{p}>0,05$ (табл. 2).

Таблиця 3

Ураження органів-мішеней у паціснтів із АГ, n (\%)

\begin{tabular}{|l|c|c|c|c|}
\hline \multicolumn{1}{|c|}{ Ознака } & $\begin{array}{c}\text { Група 1, } \\
\mathbf{n = 7 0}\end{array}$ & $\begin{array}{c}\text { Група 2, } \\
\mathbf{n = 6 9}\end{array}$ & $\begin{array}{c}\text { Група 3, } \\
\mathbf{n = 7 2}\end{array}$ & $\begin{array}{c}\text { Група 4, } \\
\mathbf{n = 6 9}\end{array}$ \\
\hline $\begin{array}{l}\text { Ураження органів- } \\
\text { мішеней }\end{array}$ & $\begin{array}{c}31 \\
(44,28 \%)\end{array}$ & $\begin{array}{c}33 \\
(47,84 \%)\end{array}$ & $\begin{array}{c}32 \\
(44,44 \%)\end{array}$ & $\begin{array}{c}29 \\
(42,03 \%)\end{array}$ \\
\hline
\end{tabular}

Примітка: $\mathrm{n}$ - кількість пацієнтів

Пацієнти всіх груп достовірно не розрізнялися за наявністю ознак ураження органів-мішеней при АГ, $\mathrm{p}>0,05$ (табл. 3) і за функціональним класом (ФК) IXC (табл. 4).

Всього IXC було діагностовано у 145 пацієнтів.

Таблиця 4

Розподіл паціснтів по функціональних класах IXC, n (\%)

\begin{tabular}{|c|c|c|c|c|}
\hline ФК & $\begin{array}{c}\text { Група 1, } \\
\mathbf{n = ~ 7 0}\end{array}$ & $\begin{array}{c}\text { Група 2, } \\
\mathbf{n = 6 9}\end{array}$ & $\begin{array}{c}\text { Група 3, } \\
\mathbf{n = ~ 7 2}\end{array}$ & $\begin{array}{c}\text { Група 4, } \\
\mathbf{n = ~ 6 9}\end{array}$ \\
\hline II & $26(37,14 \%)^{1)}$ & $25(36,23 \%)^{1)}$ & $25(34,72 \%)^{1)}$ & $28(40,58 \%)^{1)}$ \\
\hline III & $6(8,57 \%)$ & $12(17,39 \%)$ & $7(9,72 \%)$ & $4(5,78 \%)$ \\
\hline IV & $4(5,71 \%)$ & $3(4,35 \%)$ & $6(8,33 \%)$ & $1(1,45 \%)$ \\
\hline
\end{tabular}

Примітка: $\mathrm{n}$ - кількість паціснтів, ${ }^{1)}$ - достовірність різниці показників у середині груп

Групи достовірно не розрізнялися за наявністю у пацієнтів в анамнезі перенесеного інфаркту міокарду. В групі 1 ця подія відбулася 
в минулому у $6(8,57 \%)$ пацієнтів, в групі 2 - у $3(4,35 \%)$, в групі $3-$ у $6(8,33 \%)$, в групі 4 - у $6(8,7 \%), p>0,05$ у всіх випадках.

Порушення серцевого ритму спостерігали також 3 однаковою частотою: у 4 пацієнтів в групі 1 , у 3 - в групі 2 , у 4 - в групі 3 , у 3 - в групі $4, \mathrm{p}>0,05$ у всіх випадках.

Пацієнти, що страждали на OA (141 особа) за переважною локалізацією суглобового патологічного процесу розподілилися наступним чином.

Таблиця 5

Характеристика ОА за локалізацісю у паціснтів, $\mathbf{n}(\%)$

\begin{tabular}{|l|c|c|c|c|}
\hline \multicolumn{1}{|c|}{ Локалізація } & $\begin{array}{c}\text { Група 1, } \\
\mathbf{n = ~ 7 0}\end{array}$ & $\begin{array}{c}\text { Група 2, } \\
\mathbf{n = 6 9}\end{array}$ & $\begin{array}{c}\text { Група 3, } \\
\mathbf{n = 7 2}\end{array}$ & $\begin{array}{c}\text { Група 4, } \\
\mathbf{n = 6 9}\end{array}$ \\
\hline Кульшовий суглоб & $3(4,29 \%)$ & $4(5,79 \%)$ & $4(5,55 \%)$ & $6(8,69 \%)$ \\
\hline Колінний суглоб & $6(8,57 \%)$ & $7(10,14 \%)$ & $6(8,33 \%)$ & $6(8,69 \%)$ \\
\hline Суглоби хребта & $6(8,57 \%)$ & $7(10,14 \%)$ & $4(5,55 \%)$ & $3(4,35 \%)$ \\
\hline Суглоби кистей & $4(5,71 \%)$ & $3(4,28 \%)$ & $3(4,17 \%)$ & $4(6,67 \%)$ \\
\hline Суглоби стоп & $4(5,71 \%)$ & $3(4,34 \%)$ & $4(5,55 \%)$ & $3(4,35 \%)$ \\
\hline Плечові суглоби & $7(10,0 \%)$ & $6(8,69 \%)$ & $7(9,72 \%)$ & $4(6,67 \%)$ \\
\hline Ліктьовий суглоб & $6(8,57 \%)$ & $7(10,14 \%)$ & $6(8,33 \%)$ & $3(4,35 \%)$ \\
\hline
\end{tabular}

Примітка: $\mathrm{n}$ - кількість пацієнтів

За локалізацією ОА пацієнти всіх досліджуваних груп також не розрізнялися, $\mathrm{p}>0,05$ (табл. 5). Розбіжностей між групами за рентгенологічною стадією за I. Kellgren i I. Lawerens отримано не було.

Ожиріння діагностували з однаковою частотою серед пацієнтів усіх чотирьох груп: відповідний індекс маси тіла (IMT) визначали у $17(24,3 \%)$ пацієнтів групи 1 , у 19 (27,5\%) пацієнтів групи 2, у $19(26,4 \%)$ пацієнтів групи 3 і у 14 (20,3\%) пацієнта в групі 4, p > 0,05.

ХОЗЛ спостерігали у $3(4,3 \%)$ пацієнта групи 1 , у 4 (5,8\%) пацієнтів групи 2 , у $3(4,2 \%)$ пацієнтів групи 3 і у $1(1,4 \%)$ пацієнта в групі 4 , $\mathrm{p}>0,05$. Розподіл за стадіями ХОЗЛ був наступним: у 2 (18,2\%) пацієнта - стадія В і у $9(81,8 \%)$ пацієнтів - стадія С.

У всіх пацієнтів, у яких було діагностовано хронічний панкреатит, хронічний холецистит, хронічний пієлонефрит, ці хвороби були в стадії ремісії. Хронічний панкреатит спостерігали у $1(1,4 \%)$ пацієнта групи 1 , у $1(1,4 \%)$ пацієнта групи 2 , у $3(4,2 \%)$ пацієнтів групи 3 і у жодного в групі $4, \mathrm{p}>0,05$. Хронічний холецистит - у $4(5,7 \%)$ пацієнтів групи 1 , у $6(8,7 \%)$ пацієнтів групи 2 , у $4(5,6 \%)$ пацієнтів групи 3 , у $3(4,3 \%)$ пацієнтів групи $4, \mathrm{p}>0,05$, до чого лише у $3(17,6 \%)$ він був із жовчнокам'яною хворобою. Конкременти в жовчному міхурі мали розміри від 
1 мм і до 3 мм. Консервативну терапію жовчно-кам'яної хвороби не проводили жодному пацієнтові. Хронічний пієлонефрит також зустрічали з однаковою частотою серед пацієнтів всіх груп: у 3 (4,3\%) пацієнтів групи 1 , у 1 (1,4\%) пацієнта групи 2 , у 3 (4,2\%) пацієнтів групи 3 , у $3(4,3 \%)$ пацієнтів групи $4, \mathrm{p}>0,05$. Сечокам'яна хвороба зустрічалася у $7(10 \%)$ пацієнтів групи 1 , у $6(8,7 \%)$ пацієнтів групи 2, у $8(11,1 \%)$ пацієнтів групи 3 , у $7(10,1 \%)$ пацієнтів групи $4, \mathrm{p}>0,05$.

Остеопенія / остеопороз було діагностовано у 11 (15,7\%) пацієнтів групи 1 , у $16(23,2 \%)$ пацієнтів групи 2 , у $13(18,1 \%)$ пацієнтів групи 3 , у $14(20,3 \%)$ пацієнтів групи 4, p > 0,05. При цьому на основі денситометрії - у $31(57,4 \%)$ і у $23(42,6 \%)$ пацієнта остеопороз було виявлено під час рентгенографії (тобто втраті $>20 \%$ кісткової маси).

Середня концентрація вітаміну D3 в контрольній групі в серпні склала $(\mathrm{M} \pm \mathrm{SD})(75,3 \pm 18,8)$ нмоль/л, а в лютому - $(69,5 \pm 17,2)$ нмоль/л, тенденція до зниження не досягла статистичної достовірності $(\mathrm{p}=0,11)$.

Таку ж тенденцію спостерігали і в осіб похилого віку, при цьому рівні вітаміну D3 були достовірно нижче, ніж у контрольній групі.

У обстежених пацієнтів рівень вітаміну D3 склав в серпні 2018 р. $(41,1 \pm 13,7)$ нмоль/л, $\mathrm{p}=0,00$, в порівнянні 3 контролем, а в лютому 2019 р. $-(38,4 \pm 12,8)$ нмоль/л, $p=0,00$ в порівнянні $з$ контролем. Тобто ми мали достовірне зниження рівня вітаміну D3 в зимовий період, $\mathrm{p}=0,042$.

Імуногенність вакцин становить основу іiі ефективності. Вкрай важливо, щоб вакцини викликали Т-залежну імунну відповідь. В іншому разі відповідь буде короткочасною, а контакт з антигеном не буде викликати вторинну відповідь. Первинна і вторинна імунна відповідь відрізняються одна від одної за динамікою формування імунітету. Вторинна імунна відповідь буде недостатньо вираженою, якщо для імунізації використовується слабкий антиген, якщо в організмі присутні пасивно введені або активно надбані антитіла, якщо антиген вводять пацієнту з імунодефіцитом.

Показники, які характеризують імуногенність вакцини, було визначено на день вакцинації (безпосередньо перед введенням вакцини) і через 21 день після вакцинації. Отримані дані наведені в таблицях.

Під час порівняння імуногенності вакцини в осіб похилого віку порівняно $з$ молодими (контрольна група), основні показники були достовірно нижче для всіх досліджуваних серотипів вірусів грипу. Однак, в цілому у осіб похилого віку ці показники відповідали вимогам Всесвітня організація охорони здоров'я (ВОО3) ${ }^{6}$.

\footnotetext{
${ }^{6}$ Vaccines against influenza WHO position paper. Weekly Epidemiol Rec. 2012. Vol. 87(47). P. 461-476.
} 
Таблиця 6

Показники імуногенності в обстежених паціснтів до вірусу грипу A (H1N1), (M \pm SD)

\begin{tabular}{|l|c|c|c|}
\hline \multicolumn{1}{|c|}{ Показник } & $\begin{array}{c}\text { Контроль, } \\
\mathbf{n = 5 0}\end{array}$ & $\begin{array}{c}\text { Група 1, } \\
\mathbf{n = 7 0}\end{array}$ & $\begin{array}{c}\text { Група 2, } \\
\mathbf{n = 6 9}\end{array}$ \\
\hline Фактор сероконверсії & $6,87^{1) 2}$ & 5,23 & 5,31 \\
\hline $\begin{array}{l}\text { Рівень серопротекції, } \\
(\mathrm{MD} \pm \text { SD), \% }\end{array}$ & $(82,3 \pm 12,2)^{1) 2)}$ & $68,7 \pm 20,1$ & $70,7 \pm 23,8$ \\
\hline $\begin{array}{l}\text { Рівень сероконверсії, } \\
(\mathrm{MD} \pm \text { SD), \% }\end{array}$ & $\left.(76,2 \pm 14,5)^{1) 2}\right)$ & $57,3 \pm 18,4$ & $58,7 \pm 16,2$ \\
\hline $\begin{array}{l}\text { СГТ антитіл } \\
\text { [Медіана, 95\% ДI] }\end{array}$ & $\begin{array}{c}\left.89,3^{1) 2}\right) \\
{[39,4-185]}\end{array}$ & $\begin{array}{c}81,9 \\
{[40,3-178]}\end{array}$ & $\begin{array}{c}82,5 \\
{[41,4-169]}\end{array}$ \\
\hline
\end{tabular}

Примітка. $\mathrm{n}$ - кількість пацієнтів; 1) $\mathrm{p}<0,05$ під час порівняння групи 1 i контролю; 2) p < 0,05 під час порівняння групи 2 і контролю

Так, у наших пацієнтів, які отримували вакцину, відзначався достатньо високий фактор сероконверсії, як для серотипу А (H1N1) (табл. 6), так і для серотипу А (H3N2) (табл. 7) і серотипу В (табл. 8). Хоча в групі контролю, тобто у молодих, він був достовірно вище.

Таблиця 7

\section{Показники імуногенності в обстежених пацієнтів} до вірусу грипу А (H3N2), (M \pm SD)

\begin{tabular}{|c|c|c|c|}
\hline Показник & $\begin{array}{c}\text { Контроль, } \\
\text { n = 50 }\end{array}$ & $\begin{array}{c}\text { Група 1, } \\
\text { n = 70 }\end{array}$ & $\begin{array}{c}\text { Група } 2, \\
\text { n = 69 }\end{array}$ \\
\hline Фактор сероконверсії & $6,73^{1) 2}$ & 5,34 & 5,12 \\
\hline $\begin{array}{l}\text { Рівень серопротекції, } \\
(\mathrm{MD} \pm \mathrm{SD}), \%\end{array}$ & $(83,4 \pm 11,8)^{1) 2)}$ & $68,4 \pm 19,9$ & $71,2 \pm 24,2$ \\
\hline $\begin{array}{l}\text { Рівень сероконверсії, } \\
\text { (MD } \pm \text { SD), \% }\end{array}$ & $(77,4 \pm 15,2)^{1) 2}$ & $56,9 \pm 18,6$ & $58,4 \pm 17,7$ \\
\hline $\begin{array}{l}\text { СГТ антитіл } \\
{[\text { Медіана, 95\% ДІ] }}\end{array}$ & $\begin{array}{c}90,1^{1) 2}[40,5- \\
187]\end{array}$ & $\begin{array}{c}82,3 \\
{[41,1-183]} \\
\end{array}$ & $\begin{array}{c}83,4 \\
{[40,9-175]}\end{array}$ \\
\hline
\end{tabular}

Примітка: $\mathrm{n}$ - кількість пацієнтів; 1) $\mathrm{p}<0,05$ під час порівняння групи 1 i контролю; 2) p $<0,05$ під час порівняння групи 2 і контролю

Рівень серопротекції незначним чином перевищив рекомендовані ВОО3 60\% для осіб похилого віку, як для А (H1N1), A (H3N2), B, залишаючись достовірно нижче, ніж у контролі.

Рівень сероконверсії також перевищив рекомендовані ВООЗ 30\% для осіб похилого віку, як для А (H1N1), А (H3N2), В, будучи достовірно нижче, ніж у контролі. 
Середньогеометричні титри (СГТ) антитіл найбільш високими були в групі контроля (молоді особи) і значним чином підвищувалися після вакцинації в осіб похилого віку, як для серотипа А (H1N1), так і для А (H3N2) i B.

Таблиця 8

Показники імуногенності в обстежених паціснтів до вірусу грипу $B,(M \pm S D)$

\begin{tabular}{|c|c|c|c|}
\hline Показник & $\begin{array}{c}\text { Контроль, } \\
\mathbf{n}=\mathbf{5 0}\end{array}$ & $\begin{array}{c}\text { Група 1, } \\
\text { n }=70\end{array}$ & $\begin{array}{c}\text { Група } 2 \\
\text { n }=69\end{array}$ \\
\hline Фактор сероконверсії & $4,97^{12)}$ & 4,53 & 4,07 \\
\hline $\begin{array}{l}\text { Рівень серопротекції, } \\
\text { (MD } \pm \text { SD), \% }\end{array}$ & $(78,5 \pm 11,4)^{1) 2)}$ & $63,1 \pm 22,6$ & $68,2 \pm 21,7$ \\
\hline $\begin{array}{l}\text { Рівень сероконверсії, } \\
\text { (MD } \pm \text { SD), \% }\end{array}$ & $(72,5 \pm 13,8)^{1) 2}$ & $50,6 \pm 17,3$ & $53,1 \pm 15,5$ \\
\hline $\begin{array}{l}\text { СГТ антитіл } \\
\text { [Медіана, 95\% ДІ] }\end{array}$ & $\begin{array}{c}\left.84,2^{1) 2}\right) \\
{[38,5-171]}\end{array}$ & $\begin{array}{c}78,6 \\
{[42,1-184]}\end{array}$ & $\begin{array}{c}79,4 \\
{[43,5-172]}\end{array}$ \\
\hline
\end{tabular}

Примітка. $\mathrm{n}$ - кількість пацієнтів; 1) $\mathrm{p}<0,05$ п порівнянні групи 1 i контролю; 2) p $<0,05$ при порівнянні групи 2 і контролю

Імунний статус протягом життя зазнає певних змін. Зокрема, здатність лейкоцитів у осіб похилого віку до продукції цитокінів значно відрізняється від такої у молодих. Повідомлялося про збільшення кількості клітин CD4+, що продукують IЛ-4, і зниженні кількості клітин $\mathrm{CD} 4+$, що продукують фактор некрозу пухлини $\alpha$ i інтерферон (ІФН) $\gamma$ у осіб похилого віку. В той же час в іншому дослідженні було виявлено наївні, цитотоксичні і CD8+ Т-клітини пам'яті, які з віком збільшували продукцію цитокінів 1-го типу (ІФН- $\gamma$, фактор некрозу пухлини $\alpha$ і ІЛ-2). Спостерігали також збільшення старіння в пам'яті CD8+ T-клітин, що продукують цитокіни типу 2 (ІЛ-4, ІЛ-6 і ІЛ-10). Останніми роками велику увагу приділяють позаскелетним ефектам вітаміну D3, особливо його впливу на імунну систему $^{7}$.

${ }^{7}$ Manzoli L., Salanti G., De Vito C. et al. Immunogenicity and adverse events of avian influenza A H5N1 vaccine in healthy adults: multiple-treatments meta-analysis. Lancet Infect Dis. 2009. Vol. 9(8). P. 482-492 DOI: 10.1016/S1473-3099(09)70153-7.

Buonocore S., Ahern P.P., Uhlig H.H. et al. Innate lymphoid cells drive interleukin23-dependent innate intestinal pathology. Nature. 2010. Vol. 464. P. 1371-1375. DOI: 10.1038/nature08949.

Geremia A., Arancibia-Carcamo C.V., Fleming M.P. et al. IL-23-responsive innate lymphoid cells are increased in inflammatory bowel disease. J Exp Med. 2011. Vol. 208. P. 1127-1133. DOI: 10.1084/jem.20101712. 
Вихідні рівні ІЛ-23, ІЛ-4, ІЛ-19 і ІФН- $\gamma$ у пацієнтів обох груп були співставні (табл. 9). Після курсу прийому холекальциферолу, у пацієнтів групи 3 спостерігалося зниження рівня ІЛ-23. Концентрація ІФН достовірно не розрізнялася до і після курсу лікування. Протилежні результати були отримані для ІЛ-4 і ІЛ-19: після курсу вітамінотерапії серед пацієнтів групи «1» рівні цих цитокінів достовірно зростали. Поєднана профілактика з використанням вакцини і холекальциферолу відрізнялися тільки достовірно менш вираженим зниженням рівнів IЛ-4 і ІЛ-19 в порівнянні 3 профілактикою тільки холекальциферолом. У групі 4 під час повторного аналізу дані не відрізнялися від вихідних.

У дослідженнях останніх років встановлена важлива роль ІЛ-23 в розвитку хронічного запалення. Цей цитокін сприяє продукції ІЛ-17 i інших прозапальних цитокінів (ІЛ-6, фактору некрозу пухлини $\alpha$ ). Раніше було показано, що холекальциферол гальмує диференціювання Th17 і продукцію цитокінів шляхом інгібування ядерного фактору для активованих T-клітин (NFAT). Рядом дослідників була встановлена пригнічуюча дія активної форми холекальциферолу на IЛ-23 i, отже, на продукцію ІЛ-22, ІЛ-17 і гранулоцитарно-моноцитарного колонієстимулюючого фактору. Ці та інші ефекти визначають роль ІЛ-23 в патогенезі багатьох захворювань ${ }^{8}$.

Співвідношення ІФН- $\gamma / \mathrm{IЛ-4} \mathrm{у} \mathrm{пацієнтів} \mathrm{похилого} \mathrm{віку} \mathrm{на} \mathrm{вихідному}$ етапі співвідношення ІФН- $\gamma / \mathrm{IЛ-4} \mathrm{було} \mathrm{достовірно} \mathrm{вище,} \mathrm{ніж} \mathrm{у} \mathrm{контролі.}$ В групі 4 воно через 2 місяці не змінювалося, а в групах 1, 2, 3 знизилося до співставного 3 групою контролю. Тобто прийом холекальциферолу призводив до пригнічення Th1 i активації Th2 шляху імунітету.

Pearson C., Thornton E.E., McKenzie B. et al. ILC3 GM-CSF production and mobilisation orchestrate acute intestinal inflammation. Elife. 2016. Vol. 5. P. e10066. DOI: 10.7554/eLife.10066.

${ }^{8}$ Jasiulionis M.G. Abnormal Epigenetic Regulation of Immune System during Aging. Front Immunol. 2018. Vol. 9. P. 197. DOI: 10.3389/fimmu.2018.00197. eCollection 2018.

Alberti S., Cevenini E., Ostan R. et al .Age-dependent modifications of type 1 and type 2 cytokines within virgin and memory CD4+ T cells in humans . Mechanisms of Ageing and Development. 2006. Vol. 127. P. 560-566. DOI: 10.1016/j.mad.2006.01.014.

Zanni F., Vescovini R., Biasini C. et al. Marked increase with age of type 1 cytokines within memory and effector/cytotoxic CD8+ $\mathrm{T}$ cells in humans: a contribution to understand the relationship between inflammation and immunosenescence. Experimental Gerontology. 2003. Vol. 38. P. 981-987 https://doi.org/10.1016/S0531-5565(03)00160-8.

Damoiseaux J., ${ }^{14}$ Smolders J. The Engagement Between Vitamin D and the Immune System: Is Consolidation by a Marriage to Be Expected? EBioMedicine. 2018. Vol. 31. P. 9-10. DOI: 10.1016/j.ebiom.2018.04.013.

Kastelein R.A., Hunter C.A., Cua D.J. Discovery and biology of IL-23 and IL-27: related but functionall distinct regulators of inflammation. Annu Rev Immunol. 2007. Vol. 25. P. 22. DOI: 10.1146/annurev.immunol.22.012703.104758. 


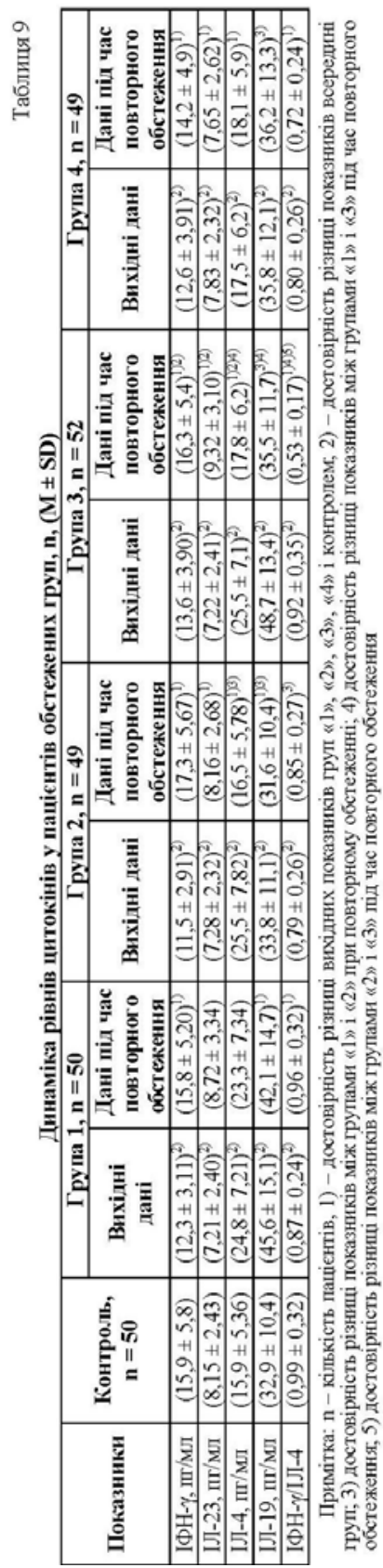


Після курсу прийому холекальциферолу у пацієнтів спостерігалося зниження рівня ІЛ-23. Концентрація ІФН- $\gamma$ достовірно не розрізнялася до і після курсу профілактики. Протилежні результати були отримані для ІЛ-4 і ІЛ-19: після курсу холекальциферола серед пацієнтів групи «1» рівні цих цитокінів достовірно зростали. Профілактика, поєднана з використанням вакцини і холекальциферолу, відрізнялася достовірно менш вираженим зниженням рівнів ІЛ-4 і ІЛ-19 в порівнянні з профілактикою

тільки холекальциферолом. Співвідношення ІФН- $\gamma / \mathrm{IЛ}-4$ у пацієнтів

похилого віку на вихідному етапі співвідношення ІФН- $/$ /ІЛ-4 було достовірно вище, ніж у контролі. В групі 4 воно через 2 місяці не змінювалося, а в групах 1, 2, 3 - знизилося до співставного з групою контролю.

Власне, людина має Th1 i Th2. Відповідь Th1 забезпечує захист від внутрішньоклітинних патогенних мікроорганізмів, пухлинних клітин i вірусів за допомогою цитотоксичних Т-клітин, NK-клітин, активованих макрофагів і антитіл з В-клітин. Основним праймуючим цитокіном, який керує диференціацією і проліферацією клітин Th1 з наївних лімфоцитів Th0 після розпізнавання антигену, є IЛ-12. Ці клітини Th1 продукують велику кількість ІФН- $\gamma$, яка забезпечує зміщений Th1 імунний шлях і в той же час функціонує як найсильніший контррегуляторний цитокін проти Th2-імунітету. Це запобігає розвитку імунітету Th2 схоже з Th2 імунітетом. ІЛ-4 є типовим цитокіном Th2. Відповідь Th2 забезпечує імунітет проти позаклітинних патогенних мікроорганізмів, і основними клітинами імунітету Th2 є В-клітини, еозинофіли і базофіли. Якщо імунітет значно зміщений до відповіді Th2, виробляється багато IЛ-4 i IЛ-10, а також ІЛ-5, і це може призвести до алергічної Ig E опосередкованої реакції або аутоімунітету, опосередкованому специфічними аутореактивними антитілами. ІЛ-4 $є$ типовим праймуючим цитокіном, який керує диференцировкою наївних Т-клітин в Th2 - шлях активації імунітету. В той же час ІЛ-4 функціонує як основний контррегуляторний цитокін, який інгібує здвиг імунної відповіді в бік імунітету Th1. Отже, ІЛ-4 i ІФН- $\gamma \in$ контррегуляторними цитокінами. IФН- $\gamma \epsilon$ типовим цитокіном Th1, а ІЛ-4 $є$ типовим цитокіном Th2. Таким чином, за їх співвідношенням ви можете знайти, який з цих двох шляхів $\epsilon$ більш вираженим або пригніченим.

\section{ВИСНОВКИ}

Імунологічна ефективність грипозної вакцини у наших пацієнтів відповідала вимогам ВООЗ для осіб похилого віку: серопротекція $>60 \%$, фактор серопротекції $>4$ (при достатньому $>2$ ), сероконверсія $>50 \%$ (при достатній $>30 \%$ ). При цьому додатковий прийом вітаміну D3 не впливав на ці показники. В групі молодих осіб імуногенність вакцини була достовірно вище. 
Поєднана профілактика 3 використанням вакцини і холекальциферолу відрізнялася достовірно менш вираженим зниженням рівнів IЛ-4 i ІЛ-19 у порівнянні 3 профілактикою тільки холекальциферолом. Співвідношення ІФН- $\gamma / \mathrm{IЛ-4} \mathrm{у} \mathrm{пацієнтів} \mathrm{похилого} \mathrm{віку} \mathrm{на} \mathrm{вихідному}$ етапі було достовірно вище, ніж у контролі. Тобто прийом холекальциферолу призводив до пригнічення Th1 i активації Th2 шляху імунітету.

Вивчення впливу холекальциферолу на стан здоров'я осіб похилого віку потребує організації контрольованих широкомасштабних досліджень.

\section{АНОТАЦІЯ}

Метою цього дослідження була оцінка імуногенності вакцини проти грипу та імунного статусу на фоні прийому холекальциферолу, вакцини проти грипу та їх комбінацій у осіб похилого віку. Об’єктом дослідження було 200 осіб, серед яких було 102 (51\%) жінки і 98 (49\%) чоловіків віком від 65 до 79 років, середній вік яких склав $(\mathrm{M} \pm \mathrm{SD})(72,4 \pm 7,1)$ років. Після рандомізації пацієнтів було розділено по 4 групах. Пацієнти в групі 1 почали прийом холекальциферолу і отримали вакцину проти грипу. Пацієнти в групі 2 отримали тільки вакцину проти грипу; пацієнти в групі 3 - тільки холекальциферол; пацієнти групи 4 обмежилися виконанням загально-гігієнічних заходів. Було показано, що імуногенність протигрипозної вакцини у наших пацієнтів відповідала вимогам ВООЗ для осіб похилого віку: серопротекція $>60 \%$, фактор серопротекції $>4$ (при достатньому $>2$ ), сероконверсія $>50 \%$ (при достатній $>30 \%$ ). При цьому додатковий прийом вітаміну D3 не впливав на ці показники. Поєднана профілактика з використанням вакцини $\mathrm{i}$ холекальциферолу відрізнялася достовірно менш вираженим зниженням рівнів ІЛ-4 і ІЛ-19 в порівнянні 3 профілактикою тільки холекальциферолом. Співвідношення ІФН- $\gamma / \mathrm{IЛ}-4$ у пацієнтів похилого віку на вихідному етапі було достовірно вище, ніж у контролі. Тобто прийом холекальциферолу призводив до пригнічення Th1 i активації Th2 шляху імунітету. У світлі представлених даних вивчення впливу холекаліціферолу на захворюваність респіраторними інфекціями потребує організації контрольованих широкомасштабних досліджень.

\section{ЛІТЕРАТУРА}

1. Thevarajan I. Breadth of concomitant immune responses prior to patient recovery: a case report of non-severe COVID-19. Nat Med, 2020. DOI: https://www.nature.com/articles/s41591-020-0819-2.

2. Adit A., Blatchford P., Breese K. et al. High-Dose Monthly Vitamin D for Prevention of Acute Respiratory Infection in Older LongTerm Care Residents: A Randomized Clinical Trial. Epub., 2016. DOI: 10.1111/jgs.14679. 
3. Bergman P., Lindh U., Björkhem-Bergman L.et al. Vitamin D and Respiratory Tract Infections: A Systematic Review and Meta- Analysis of Randomized Controlled Trials. 2013. DOI: 10.1371/journal.pone.0065835

4. Daneshkhah A., Agrawal V., Eshein A. et al. The Possible Role of Vitamin D in Suppressing Cytokine Storm and Associated Mortality in COVID-19 Patients. 2020. DOI https://doi.org/10.1101/2020.04.08.20058578.

5. Наказ МО3 України №110 від 14.02.2012 «Про затвердження форм первинної облікової документації та інструкцій щодо їх заповнення, що використовуються у закладах охорони здоров'я незалежно від форми власності та підпорядкування». URL: https://www.moz.gov.ua/ua/portal/dn_20120214_110.html.

6. Vaccines against influenza WHO position paper. Weekly Epidemiol Rec. 2012. Vol. 87(47). P. 461-476.

7. Manzoli L., Salanti G., De Vito C. et al. Immunogenicity and adverse events of avian influenza A H5N1 vaccine in healthy adults: multipletreatments meta-analysis. Lancet Infect Dis. 2009. Vol. 9(8). P. 482-492 DOI: 10.1016/S1473-3099(09)70153-7.

8. Buonocore S., Ahern P.P., Uhlig H.H. et al. Innate lymphoid cells drive interleukin-23-dependent innate intestinal pathology. Nature. 2010. Vol. 464. P. 1371-1375. DOI: 10.1038/nature08949.

9. Geremia A., Arancibia-Carcamo C.V., Fleming M.P. et al. IL-23-responsive innate lymphoid cells are increased in inflammatory bowel disease. J Exp Med. 2011. Vol. 208. P. 1127-1133. DOI: 10.1084/ jem.20101712.

10. Pearson C., Thornton E.E., McKenzie B. et al. ILC3 GM-CSF production and mobilisation orchestrate acute intestinal inflammation. Elife. 2016. Vol. 5. P. e10066. DOI: 10.7554/eLife.10066.

11. Jasiulionis M.G. Abnormal Epigenetic Regulation of Immune System during Aging. Front Immunol. 2018. Vol. 9. P. 197. DOI: 10.3389/ fimmu.2018.00197. eCollection 2018.

12. Alberti S., Cevenini E., Ostan R. et al. Age-dependent modifications of type 1 and type 2 cytokines within virgin and memory CD4+ T cells in humans. Mechanisms of Ageing and Development. 2006. Vol. 127. P. 560-566. DOI: 10.1016/j.mad.2006.01.014.

13. Zanni F., Vescovini R., Biasini C. et al. Marked increase with age of type 1 cytokines within memory and effector/cytotoxic CD8+ $\mathrm{T}$ cells in humans: a contribution to understand the relationship between inflammation and immunosenescence. Experimental Gerontology. 2003. Vol. 38. P. 981-987. https://doi.org/10.1016/S0531-5565(03)00160-8.

14. Damoiseaux J., Smolders J. The Engagement Between Vitamin D and the Immune System: Is Consolidation by a Marriage to Be Expected? EBioMedicine. 2018. Vol. 31. P. 9-10. DOI: 10.1016/j.ebiom.2018.04.013. 
15. Kastelein R.A., Hunter C.A., Cua D.J. Discovery and biology of IL-23 and IL-27: related but functionally distinct regulators of inflammation. Annu Rev Immunol. 2007. Vol. 25. P. 221-242. DOI: 10.1146/ annurev.immunol.22.012703.104758.

\section{Information about authors:}

Grishyna O. I.,

Candidate of Medical Sciences,

Lead Research Associate of Laboratory and Clinical Department of Immunopharmacology SI "Mechnikov Institute of Microbiology and Immunology of National Academy of Medical Sciences of Ukraine"

14-16, Pushkinska str., Kharkiv, 61057, Ukraine

Menkus O. V.,

Research Associate of Laboratory and Clinical Department of Immunopharmacology SI "Mechnikov Institute of Microbiology and Immunology of National Academy of Medical Sciences of Ukraine"

14-16, Pushkinska str., Kharkiv, 61057, Ukraine 